\title{
Minireview
}

\section{Genetic engineering for improvement of Musa production in Africa}

\author{
Leena Tripathi \\ International Institute of Tropical Agriculture (IITA), Nigeria; C/o L. W. Lambourn; Carolyn House; 26 Dingwall Rd; \\ Croydon CR9 3EE; UK. Tel: 234-2-241-2626. Fax: 234-2-241-2221. Email: I.tripathi@cgiar.org.
}

Accepted 19 November 2003

\begin{abstract}
Bananas and plantains (Musa sp.) are the most important staple food and source of carbohydrates in many countries of Africa. The production is often constrained by many pests and diseases. In order to augment conventional breeding and to avoid constraints imposed by some pests and pathogens, transgenic approaches are being considered. The development of transgenic Musa plants has been achieved recently using the microprojectile bombardment procedure or Agrobacterium-mediated transformation. The transgenic approach shows potential for the genetic improvement of the crop using a wide set of transgenes currently available which may confer resistance to nematode pests, fungal, bacterial and viral diseases. This article discusses the applications of genetic engineering for the enhancement of Musa production.
\end{abstract}

Key Words: Musa, genetic engineering, crop improvement.

\section{INTRODUCTION}

Bananas and plantains (Musa sp.) are a major staple food, supplying up to $25 \%$ of the carbohydrates for approximately 70 million people in Africa's humid forest and mid-altitude regions (IITA, 1998). World Musa production is currently about 97 million tones annually (FAOSTAT, 2003), of which bananas cultivated for the export trade accounts for only $10 \%$. Hence, bananas and plantains are important for food security in the humid tropics and provide income to the farmers. Many pests and diseases have significantly affected Musa cultivation. Black sigatoka (Mycosphaerella fijiensis), Fusarium wilt (Fusarium oxysporum f. sp. cubense), bacterial wilts, viruses (causing Banana bunchy-top and Banana streak) and nematodes cause significant crop losses worldwide (Carlier et al., 2000; de Waele, 2000; Ploetz and Pegg, 2000; Thwaites et al., 2000,). Development of diseaseresistant Musa by conventional breeding remains a difficult endeavor because of the long generation times, various levels of ploidy, sterility of most edible cultivars, and limited genetic variability. Therefore, genetic engineering may offer an alternative method for crop enhancement. This paper reviews the strategies for banana transformation to address the major constraints to banana and plantain production in Africa.

\section{GENETIC TRANSFORMATION OF MUSA}

Genetic transformation has become an important tool for crop improvement. Relative success in genetic engineering of bananas and plantains has been achieved recently, enabling the transfer of foreign genes into the plant cells. Genetic transformation using microprojectile bombardment of embryogenic cell suspensions is now routine (Becker et al., 2000; Cote et al, 1997; Sagi et al., 1995). However, Agrobacterium-mediated transformation offers several advantages over direct gene transfer methodologies (particle bombardment, electroporation, 
etc), such as the possibility of transferring only one or few copies of DNA fragments carrying the genes of interest at higher efficiencies with lower cost and the transfer of very large DNA fragments with minimal rearrangement (Gheysen et al., 1998; Hansen and Wright, 1999; Shibata and Liu, 2000).

Musa was generally regarded as recalcitrant for Agrobacterium-mediated transformation. Hernandez et al. (1999) has reported that $A$. tumefaciens is compatible with banana indicating the potential for genetic transformation by this means. The protocol has been developed for Agrobacterium-mediated transformation of embryogenic cell suspensions of the banana cultivar 'Rasthali' (Ganapathi et al., 2001). At present most of the transformation protocols use cell suspensions. However, establishing cell suspensions is a lengthy process and cultivar dependent. The protocol has also been established using shoot tips from various cultivars of Musa (May et al., 1995; Tripathi et al., 2002). This technique is applicable to a wide range of Musa cultivars irrespective of ploidy or genotype (Tripathi et al., 2002). This process does not incorporate steps using disorganized cell cultures but uses micropropagation, which has the important advantage that it allows regeneration of homogeneous populations of plants in a short period of time. This procedure offers several potential advantages over the use of embryogenic cell suspensions (ECS) as it allows for rapid transformation of Musa species.

\section{RESISTANCE TO FUNGAL DISEASES}

Many fungal diseases have significantly affected Musa cultivation in Africa. Fusarium wilt caused by Fusarium oxysporum f. sp. cubense, has been reported to infect highland bananas in Uganda (Swennen and Vuylsteke, 2001), but symptoms are atypical and severity is not well known. Black sigatoka, caused by the fungus Mycosphaerella fijiensis f. sp. cubense, is the most devastating disease of Musa in Africa. It causes significant reductions in leaf area, yield losses of $50 \%$ or more, premature ripening, and has a wider host range that includes the plantains, dessert and cooking bananas (Ploetz, 2001). Black sigatoka is controlled with frequent applications of fungicides and cultural practices, such as the removal of affected leaves, and adequate spacing of plants and efficient drainage within plantation (Ploetz, 2001). These control methods are either require high levels of expensive inputs or have a high labour requirement, which adds to the cost burden to the grower.

The most attractive strategy for black sigatoka control in Musa is probably the production of disease resistant plants through the transgenic approach. These approaches could include the expression of genes encoding plant, fungal or bacterial hydrolytic enzymes
(Lorito et al., 1998), genes encoding elicitors of defense response (Keller et al., 1999) and antimicrobial peptides (AMPs; Cary et al., 2000; Li et al., 2001). Antimicrobial peptides have a broad-spectrum antimicrobial activity against fungi as well as bacteria and most are non-toxic to plant and mammalian cells. Examples of AMPs are magainin from the African clawed frog (Bevins and Zasloff, 1990; Zasloff, 1987), cecropins from the giant silk moth (Boman and Hultmark, 1987), mammalian (Ganz and Lehrer, 1994) and plant defensins (Broekaert et al., 1995). The cecropin (Alan and Earle, 2002; De Lucca et al., 1997) and its derivatives (D4E1: Cary et al., 2000; Rajasekaran et al., 2001) as well as its hybrids peptides with melittin (Osusky et al., 2000) have been found to inhibit the in vitro growth of several important fungal pathogens. The synthetic cecropin-melittin chimeric peptide provided field-level resistance against Verticillium dahliae in potato (Osusky et al., 2000).

Similarly, magainin is effective against many plant pathogenic fungi (Kristyanne et al., 1997; Zasloff, 1987). $\mathrm{Li}$ et al. (2001) reported enhanced disease resistance in transgenic tobacco expressing Myp30, a magainin analogue. Another substitution analogue, MSI-99, when expressed in tobacco via chloroplast transformation conferred both in vitro and in planta resistance to plant pathogenic bacteria and fungi (De Gray et al., 2001). Recently, Chakrabarti et al. (2003) reported successful expression of this synthetic peptide and enhanced disease resistance in transgenic tobacco and banana. On the basis of their broad-spectrum activity against fungal pathogens, individual or combined expression of cecropin, magainin and their derivatives in Musa may result in increased resistance to several pathogens.

There are many reports on the application of plant proteins with distinct antimicrobial activities (Broekaert et al., 1997; Yun et al., 1997). Thionins are highly abundant polypeptides with antifungal activities. Epple et al. (1997) observed that constitutive over expression of thionin in transgenic Arabidopsis resulted in enhanced resistance against $F$. oxysporum $f$. sp. matthiole. There are number of known plant defensins. The radish defensin Rs-AFP2 conferred partial resistance to the tobacco pathogen Alternaria longipes (Terras et al., 1995) where as defensin from alfalfa (alfAFP) provided resistance to $V$. dahliae in potato in the greenhouse as well as in the field (Gao et al., 2000). Kanzanki et al. (2002) reported the overexpression of the WTI defensin from wasabi (Japanese horse radish) conferring enhanced resistance to blast fungus in transgenic rice.

The AMPs of plant origin may be the potent candidates for fungal resistance in Musa as they have high in vitro activity to Mycospaerella fijiensis and Fusarium oxysporum $f$. sp. cubense and also they are non-toxic to human or banana cells. Several hundreds of transgenic lines of Musa especially plantains expressing AMPs have been developed at KULeuven (Remy, 2000), but none of these transgenic plants has been used in field trials due 
to the lack of biosafety guidelines in most tropical countries.

\section{RESISTANCE TO BACTERIAL DISEASES}

The livelihoods of millions of Ugandan farmers have been threatened by the current outbreak of bacterial wilt disease produced by infection with Xanthomonas campestris pv. musacearum (Xcm; Tushemereirwe et al., 2002). Xcm infection can result in heavy banana crop production losses and affect banana productivity by not only causing wilting and death of young banana propagules, but also by severe crop yield reductions in mother crop and subsequent ratoon plant production cycles. Xcm is gradually spreading in East Africa and if unchecked could result in massive losses. Studies in Uganda show that the disease attacks all varieties of banana, locally known as matooke, a staple food in Uganda and parts of Kenya and Tanzania.

To date, no banana germplasm exhibiting resistance to the disease has been identified. Use of genetic transformation technology with bactericidal transgenes encoding for peptides such as cecropins and lysozyme, may offer an alternative solution to these problems. Native, mutant and synthetic cecropins are active against a wide range of plant pathogenic bacteria including several Xc pathovars whereas they exert no toxicity at bactericidal concentration to cultured cells or protoplasts of several plant species (Kaduno-Okuda et al., 1995; Nordeen et al., 1992; Rajasekaran et al., 2001). Therefore, cecropins are considered as potential candidates to protect plants against bacterial pathogens. Transgenic tobacco plants expressing cecropins have increased resistance to Pseudomonas syringae pv. tabaci, the cause of tobacco wildfire (Huang et al., 1997).

Another antibacterial protein is lysozyme, either from bacteriophage, hen eggs or bovine. The lysozyme attacks the murein layer of bacterial peptidoglycan resulting in cell wall weakening and eventually leading to lysis of both Gram-negative and Gram-positive bacteria. The lysozyme genes have been used to confer resistance against plant pathogenic bacteria in transgenic tobacco plants (Trudel et al., 1995). T4L, from the T4bacteriophage, also has been reported to enhance resistance of transgenic potato against Erwinia carotovora, which causes bacterial soft rot (Düring et al., 1993). Transgenic apple plants with the T4L gene showed significant resistance to fire blight infection (Ko, 1999). Human lysozyme transgenes have conferred disease resistance in tobacco through inhibition of fungal and bacterial growth, suggesting the possible use of the human lysozyme gene for controlling plant disease (Nakajima et al., 1997). There is evidence of efficacy of bovine lysozyme isozyme c2 (BVLZ) transgene against a variety of Xanthomonas campestris strains in both monocotyledon and dicotyledon crops including tomato, tobacco, rice and potato (Mirkov and Fitzmaurice, 1995). Since this bactericidal transgene has been shown to function in monocot, has clear efficacy against at least several strains of $X$. campestris, and has been demonstrated to be a suitable nontoxic food preservative and bactericidal agent, its availability and usefulness as a transgene for resistance to $X$. campestris in Musa has a high probability of success.

\section{RESISTANCE TO VIRAL DISEASES}

Banana bunchy top, caused by Banana bunchy top virus (BBTV), genus Nanavirus is one of the most threatening diseases in the world, as infected plants do not produce fruit. So far, only a few areas are affected in Africa (Swennen and Vuylsteke, 2001). Banana streak virus (BSV), genus Badnavirus has however had a major impact on banana and plantain production in Africa (Swennen and Vuylsteke, 2001). BSV infection induces yield losses and restricts movement of improved germplasm (due to quarantine restrictions), particularly in sub-Saharan Africa. Recent reports indicate that BSV infection may arise from the activation of viral sequences that are integrated into the Musa genome (Geering et al., 2001; Harper et al., 1999; Ndowora et al., 1999). Tissue culture and hybridization through conventional breeding may be triggers for the activation of the integrant to produce BSV infection (Delanoy et al., 2003). This problem of virus activation suggests that traditional techniques for virus eradication, such as meristem tip culture, are not appropriate because these treatments would merely activate the integrated BSV sequences. Recently, Helliot et al. (2003) have reported that the antiretroviral and anti-hepadnavirus molecules, adefovir, tenofovir and 9-(2-phosphonomethoxyethyl)-2,6diaminopurine (PMEDAP), efficiently eradicate the episomal form of Banana streak virus (BSV) from banana plants.

Unfortunately, there appear to be no strategies to generate high-level resistance to the plant dsDNA or pararetroviruses, including the badnaviruses. Researchers at International Institute of Tropical Agriculture (IITA), Nigeria in collaboration with John Innes Centre $(\mathrm{JIC}), \mathrm{UK}$, are attempting to generate transgenic plants resistant to BSV (including expression of integrated sequences) based on the novel approach of gene silencing. This involves preprogramming plant cells to specifically degrade viral sequences that are homologous to the expressed transgene.

\section{RESISTANCE TO NEMATODES}

Nematodes are recognized as severe production constraints to bananas and plantains (Gowen and Queneherve, 1990), with losses due to nematodes 
estimated at about 20\% worldwide (Sasser and Freckman, 1987). Locally however, losses of $40 \%$ or greater can frequently occur, particularly in areas prone to tropical storms due to toppling as a result of wind damage on affected plants. Nematode management in bananas and plantains is mainly based on crop rotation and chemical control (Gowen and Queneherve, 1990). However, crop rotation is not often practiced and use of nematicides is often not practical or affordable to subsistence farmers or is environmentally unacceptable. There is evidence that nematode resistance and tolerance sources, though limited, are present in the Musa gene pool (Pinochet, 1996). Some resistance has been identified against the most damaging nematode species, the burrowing nematode (Radopholus similis), but this needs to be combined with consumer acceptable traits. However, Pratylenchus $s p$. causes more losses than $R$. similis. Furthermore, several species of nematodes are often present together, necessitating a broad spectrum resistance in order to reduce these losses significantly.

There are several possible approaches for developing transgenic plants with improved nematode resistance. The use of proteinase inhibitors (PIs), as nematode antifeedants, is an important element of natural plant defence strategies (Ryan, 1990). This approach offers prospects for novel plant resistance against nematodes and reduces use of nematicides. The potential of PIs for transgenic crop protection is enhanced by a lack of harmful effects when humans consume them in seeds such as rice and cowpea. Cysteine Pls (cystatins) are inhibitors of cysteine proteinases and have been isolated from seeds of a wide range of crop plants consumed by man including those of sunflower, cowpea, soybean, maize and rice (Atkinson et al., 1995). Cysteine proteinases are not involved in mammalian digestion. Transgenic expression of Pls provides effective control of both cyst and root-knot nematodes. The cystatins Oc-I and an engineered variant Oc-I $\triangle D 86$ was shown to mediate nematode resistance when expressed in tomato hairy root (Urwin et al., 1995), Arabidopsis plants (Urwin et al., 1997), rice (Vain et al., 1998) and pineapple (Urwin et al., 2000). The partial resistance $(70 \pm 9 \%)$ was conferred in a small-scale potato field trial on a susceptible cultivar by expressing cystatins under control of the CaMV35S promoter (Urwin et al., 2001). There is no evidence that expression of cystatins impairs plant growth or yield in trials. The enhanced transgenic plant resistance to nematodes has been demonstrated by using dual proteinase inhibitor constructs (Urwin et al., 1998). Full resistance is achieved by pyramiding a cystatin with natural resistance genes (Urwin, 2003). Since this nematicidal transgene not only has been shown to function in rice, which like Musa is a monocotyledon, and also has clear efficacy against a wide range of nematode species and has been consumed for years from foods such as seeds of rice and maize by human beings, its usefulness as a transgene for development of transgenic Musa for resistance to nematodes can be evaluated as having a high probability of success.

The other strategies for nematode resistance include the use of natural resistance genes (R-genes), lectins and Bacillus thuringiensis (Bt) genes. Several R-genes are targeted against nematodes. The Hs1pro-1 from a wild species of beet confers resistance to the cyst nematode Heterodera schachlii (Cai et al., 1997). The Mi1.2 gene of tomato confers resistance against Meloidogyne species (Milligan et al., 1998). To date there has been no reports of Mi-1.2 being functional after transfer to a plant other than tomato (Hwang and Williamson, 2003).

Some lectins such as snowdrop lectins (GNA) have biological activity against nematodes (Burrows et al., 1998). But many lectins have toxic effects on insects and mammals (Pusztai et al., 1996). Concerns regarding toxicological safety may prove a substantial limitation to the future commercial development of lectins. Some Bt proteins are effective against saprophagous nematodes (Borgonie et al., 1996). The Cry5B protein is toxic to wild type $C$. elegans whereas some mutants of $C$. elegans are resistant to it but susceptible to Cry6A toxin (Marroquin et al., 2000). The approach using Cry genes has potential for plant nematode control (Wei et al., 2003).

\section{BIOSAFETY}

New technologies always have risks that demand careful consideration in advance of wide scale adoption in the field. Biosafety measures are necessary as a matter of sound public policy. There are two main concerns: environmental effects and human health. Functioning biosafety systems are required to ensure the safe application of GM crops and equitable access to benefits by all sectors of communities. Many African countries have made impressive progress in biotechnology and biosafety (Zidenga, 2003). To implement a national biosafety system, it is important for countries to identify the goals and objectives of their system and the existing context for biotechnology and biosafety oversight. Along with the development of biosafety frameworks in Africa, there is a greater need to improve public understanding of biotechnology. The biosafety framework must not be a means to deprive Africa of a promising technology, but a way of ensuring safe application of transgenic crops.

\section{CONCLUSIONS}

This review describes the enormous potential for genetic manipulation of Musa species for disease and pest resistance using the existing transformation systems. The use of appropriate constructs may allow the production of nematode, fungus, bacterial and virus-resistant plants in 
a significantly shorter period of time than using conventional breeding, especially if several traits can be introduced at the same time. It may also be possible to incorporate other characteristics such as drought tolerance, thus extending the geographic spread of banana and plantain production, and thus contributing significantly to food security and poverty alleviation in Africa.

\section{REFERENCES}

Alan AR, Earle ED (2002) Sensitivity of bacterial and fungal pathogens to the lytic peptides, MSI-99, magainin II, and cecropin B. Mol. PlantMicrobe Interact. 15:701-708.

Atkinson, H.J., Urwin, P.E., Hansen, E., McPherson, M.J. (1995) Designs for engineered resistance to root-parasitic nematodes. Trends Biotechnol. 13:369-374.

Becker DK, Dugdale B, Smith MK, Harding RM, Dale JL (2000). Genetic transformation of Cavendish banana (Musa sp. AAA group) cv. Grand Nain via microprojectile bombardment. Plant Cell Rep. 19:229234.

Bevins CL, Zasloff M (1990). Peptides from frog skin. Ann. Rev Biochem. 59:395-414.

Boman HG, Hultmark D (1987). Cell free immunity in insects. Ann. Rev. Microbiol. 41: 103-126.

Borgonie G, Claeys M, Leyns F, Arnaut G, De Waele D, Coomans A (1996). Effect of nematicidal Bacillus thuringiensis strains on freeliving nematodes. Fund. App. Nematology 19: 391-398.

Broekaert WF, Cammue BPA, De Bolle M, Thevissen k, De Samblanx G, Osborn RW (1997). Antimicrobial peptides from plants. Crit. Rev. Plant Sci. 16: 297-323.

Broekaert WF, Terras FRG, Cammue BPA, Osborn RW (1995). Plant defensins: novel antimicrobial peptides as components of the host defense system. Plant Physiol. 108:1353-1358.

Burrows RP, Barker ADP, Newell CA, Hamilton WDO (1998) Plantderived enzyme inhibitors and lectins for resistance against plantparasitic nematodes in transgenic crops. Pesticide Sci. 52:176-183.

Cai DG, Kleine M, Kifle S, Harloff HJ, Sandal NN (1997). Positional cloning of a gene for nematode resistance in sugar beet. Science 275:832-834.

Carlier J, Fouré E, Gauhl F, Jones DR, LePoivre P, Mourichon X, Pasberg-Gauhl C, Romero RA (2000). Black leaf streak. In: Jones DR (ed) Diseases of Banana, Abaca and Enset. CAB International, $544 \mathrm{p}$.

Cary JW, Rajasekaran K, Jaynes JM, Cleveland TE (2000). Transgenic expression of a gene encoding a synthetic antimicrobial peptide results in inhibition of fungal growth in vitro and in planta. Plant Sci. 154:171-181.

Chakrabarti A, Ganapathi TR, Mukherjee PK, Bapat VA (2003). MSI-99, a magainin analogue, imparts enhanced disease resistance in transgenic tobacco and banana. Planta 216:587-596.

Côte FX, Legavre T, Grapin A, Valentin B, Frigout O, Babeau J, Meynard D, Bakry F, Teisson C, 1997. Genetic transformation of embryogenic cell suspension in plantain (Musa AAB) using particle bombardment. In: Proceedings of the international symposium on biotechnology of tropical and subtropical species: Part 1. Acta Hort. 460.

De Gray G, Rajasekaran K, Smith F, Sanford J, Daniell H (2001). Expression of an antimicrobial peptide via the chloroplast genome to control phytopathogenic bacteria and fungi. Plant Physiol. 127:852862.

De Lucca AJ, Bland JM, Jacks TJ, Grimm C, Cleveland TE, Walsh TJ (1997). Fungicidal activity of cecropin A. Antimicrobial Agents in Chemotherapy 41:481- 483.

De Waele D (2000) Root knot nematodes. In: Jones DR (ed) Diseases of Banana, Abaca and Enset. CAB International, pp. 544.

Delanoy M, Salmon M, Kummert J (2003). Development of real-time PCR for the rapid detection of episomal Banana streak virus (BSV). Plant Dis. 87: 33-38.
Düring K, Porsch P, Fladung M, Lörz H (1993). Transgenic potato plants resistant to the phytopathogenic bacterium Erwinia carotovora. Plant J. 3:587-598.

Epple P, Apel K, Bohlmann H (1997). Over expression of an endogenous thionin enhances resistance of Arabidopsis against fusarium oxysporum. Plant Cell 9:509-520.

FAOSTAT Agriculture Data (2003) http://apps.fao.org.

Ganapathi TR, Higgs NS, Balint-Kurti PJ, Arntzen CJ, May GD, Van Eck JM (2001) Agrobacterium -mediated transformation of the embryogenic cell suspensions of the banana cultivars Rasthali (AAB). Plant Cell Rep. 20:157-162.

Ganz T, Lehrer RI (1994). Defensins. Cur. Opin. Immunol. 6:584- 589.

Gao A, Hakimi SM, Mittanck CA, Wu Y, Woerner BM, Stark DM, Shah DM, Liang J, Rommens CMT (2000). Fungal pathogen protection in potato by expression of a plant defensin peptide. Nat. Biotechnol. 18:1307-1310.

Geering ADW, Olszwski NE, Dahal G, Thomas JE, Lockhart BEL (2001). Analysis of the distribution and structure of integrated Banana streak virus DNA in a range of Musa cultivars. Mol. Plant Pathol. 2:207-213

Gheysen G, Angenon G, Montague MV (1998). Agrobacteriummediated plant transformation: a scientifically intriguing story with significant application. In: Lindsey K (ed) Transgenic plant research. Harwood Academic Press, Netherlands, pp. 1-33

Gowen S, Queneherve P (1990). Nematode parasites of banana, plantains and abaca. In: Luc M, Sikora RA, Bridge J (eds) Plant parasitic nematodes in subtropical and tropical agriculture, $C A B$ International, pp. 431-460.

Hansen G, Wright MS (1999). Recent advances in transformation of plants. Trends Plant Sci. 4:226-231.

Harper G, Osuji J, Heslop-Harrison JS, Hull R (1999). Integration of banana streak badnavirus into the Musa genome: molecular and cytogenetic evidence. Virology 255:207-213.

Helliot B, Panis B, Frison E, De Clercq E, Swennen R, Lepoivre P, Neyts J (2003) The acyclic nucleoside phosphonate analogues, adefovir, tenofovir and PMEDAP, efficiently eliminate banana streak virus from banana (Musa sp.) Antiviral Res. 59:121-126.

Hernandez JBP, Remy S, Sauco VG, Swennen R, Sagi L (1999). Chemotactic movement and attachment of Agrobacterium tumefaciens to banana cells and tissues. J. Plant Physiol. 155:245250.

Huang Y, Nordeen RO, Di M, Owens LD, McBeth JH (1997). Expression of an engineered cecropin gene cassette in transgenic tobacco plants confers disease resistance to Pseudomonas syringae pv. tabaci. Phytopathology 87:494-499.

Hwang CF, Williamson VM (2003). Leucine-rich repeat-mediated intramolecular interactions in nematode recognition and cell death signaling by the tomato resistance protein Mi. Plant J. 34: 585-593.

IITA Annual Report 1998, http://www.iita.org/info/ar98.

Kaduno-Okuda K, Taniai K, Kato Y, Kotani E, Yamakaula M (1995). Effects of synthetic Bombyx mori cecropin B on growth of plant pathogenic bacteria. J. Inv. Pathology 65: 309-319.

Kanzaki H, Nirasawa S, Saitoh $H$, Ito M, Nishihara M, Terauchi $R$, Nakamura I (2002). Over expression of the wasabi defensin gene confers enhanced resistance to blast fungus (Magnaporthe griea) in transgenic rice. Theor. App. Gen. 105:809-814.

Keller H, Pamboukdjian N, Ponchet M, Poupet A, Delon R, Verrier JL, Roby D, Ricei P (1999). Pathogen induced elicitin production in transgenic tobacco generates a hypersensitive response and nonspecific disease resistance. Plant Cell 11:223- 235.

Ko K (1999). Attacin and T4 lysozyme transgenic 'Galaxy' apple: Regulation of transgene expression and plant resistance to fire blight (Erwinia amylovora). Ph.D dissertation, Cornell University, NY.

Kristyanne ES, Kim KS, Stewart JM (1997). Magainin 2 effects on the ultrastructure of five plant pathogens. Mycologia 89:353-360.

Li Q, Lawrence CB, Xing HY, Babbitt RA, Bass WT, Maiti IB, Everett NP (2001). Enhanced disease resistance conferred by expression of an antimicrobial magainin analogue in transgenic tobacco. Planta 212:635-639.

Lorito M, Woo SL, Garcia I, Collude G, Harman GE, Pintor-Toro JA, Filippone E, Muccifora S, Lawrence CB, Zoina A, Tuzun S, Scala F, Fernandez IG (1998). Genes from mycoparasitic fungi as a source for 
improving plant resistance to fungal pathogens. Proc. Natl. Acad. Sci. USA 95:7860-7865.

Marroquin LD, Elyassnia D, Griffits JS, Aroian RV (2000) Bacillus thuringiensis (Bt) toxin susceptibility and isolation of resistance mutants in the nematode Caenorhabditis elegans. Genetics 155:1693-99.

May GD, Rownak A, Mason H, Wiecko A, Novak F J, Arntzen CJ (1995). Generation of transgenic banana (Musa acuminata) plants via Agrobacterium-mediated transformation. Bio/Technology 13:486-492.

Milligan SB, Bodeau J, Yaghoobi J, Kaloshian I, Zabel P, Williamson VM (1998). The Root knot nematode resistance gene Mi from tomato is a member of the Leucine zipper, nucleotide binding, Leucine-rich repeat family of plant genes. Plant Cell 10:1307-1320.

Mirkov TE, Fitzmaurice LC (1995). Protection of plants against plant pathogens. United States Patent No. 5422108.

Nakajima H, Muranaka T, Ishige F, Akutsu K, Oeda K (1997). Fungal and bacterial disease resistance in transgenic plants expressing human lysozyme. Plant Cell Rep. 16: 674-679.

Ndowora T, Dahal G, LaFleur D, Harper G, Hull R, Olzewski NE, Lockhart BEL (1999). Evidence that badnavirus infection in Musa can originate from integrated pararetroviral sequences. Virology 255: 214220.

Nordeen RO, Sinden SL, Jaynes JM, Owens LD (1992). Activity of cecropin SB37 against protoplasts from several plant species and their bacterial pathogens. Plant Sci. 82:101-107.

Osusky M, Zhou G, Osuska L, Hancock RE, Kay WW, Mitra S (2000). Transgenic plants expressing cationic peptide chimeras exhibit broad-spectrum resistance to phytopathogens. Nat. Biotechnol. 18:1162-1166.

Pinochet J (1996) Review of past research on Musa germplasm and nematode interactions. In: Frison EA, Horry JP, De Waele D (eds) New Frontiers in Resistance Breeding for Nematodes, Fusarium and Sigatoka. INIBAP, France pp 32-44.

Ploetz RC (2001). The most important disease of a most important fruit. www.apsnet.org/education/feature/banana/Top.html

Ploetz RC, Pegg KG (2000). Fusarium Wilt. In: Jones DR (ed) Diseases of Banana, Abaca and Enset. CAB International, $544 \mathrm{p}$.

Pusztai A, Koninkx J, Hendrik H, Kok W, Hulscher S (1996). Effect of the insecticidal Ganlanthus nivalis agglutinin on metabolism and the activities of brush border enzymes in the rat small intestine. J. Nutr. Biochem. 7:677-682.

Rajasekaran K, Stromberg KD, Cary JW, Cleveland TE (2001). Broadspectrum antimicrobial activity in vitro of the synthetic peptide D4E1. J Agric. Food Chem. 49:2799-2803.

Remy S (2000). Genetic Transformation of Banana (Musa sp.) for disease Resistance by Expression of Antimicrobial Proteins PhD thesis KUL, Belgium.

Ryan CA (1990). Proteinase inhibitors in plants: Genes for improving defences against insects and pathogens. Ann. Rev. Phytopath. 28:425-449

Sagi L, Panis B, Remy S, Schoofs H, De Smet K, Swennen R, Cammue B (1995). Genetic transformation of banana (Musa sp.) via particle bombardment. Bio/Technology 13:481-485.

Sasser JN, Freckman DW (1987). A world perspective on nematology: the role of the Society. In: Veech JA, Dickson DW (eds) Vistas on Nematology. Society of Nematologists, USA, pp. 7-14.

Shibata D, Liu YG (2000). Agrobacterium-mediated plant transformation with large DNA fragments. Trends plant Sci. 5:354-357.

Swennen R, Vuylsteke D (2001). Banana. In: Raemaekers RH (ed) Crop Production in Tropical Africa, DGIC, Belgium, pp. 530-552.
Terras FRG, Eggermont K, Kovaleva V, Raikhel N, Osborn R, Kester A, Rees SB, Vanderleyden J, Cammue BPA, Broekaert WF (1995). Small cysteine-rich antifungal proteins from radish (Raphanus sativus L.): Their role in host defense and their constitutive expression in transgenic tobacco leading to enhanced resistance to a fungal disease. Plant Cell 7:573-588.

Thwaites R, Eden-Green SJ, Black R (2000). Diseases caused by bacteria. In: Jones DR (ed) Diseases of Banana, Abaca and Enset. CAB International, pp. 544

Tripathi L, Hughes Jd'A, Tenkouano A (2002) Production of transgenic Musa varieties for sub-Saharan Africa. $3^{\text {rd }}$ International Symposium on the Molecular and Cellular Biology of Banana http://www.promusa.org/publications/leuven-abstracts.pdf.

Trudel J, Potvin C, Asselin A (1995). Secreted hen lysozyme in transgenic tobacco: Recovery of bound enzyme and in vitro growth inhibition of plant pathogens. Plant Sci. 106:55-62.

Tushemereirwe WK, Kangire A, Smith J, Nakyanzi M, Karyeija R, Kataama D, Musiitwa C (2002). An out break of Banana bacterial wilt in Mukono and Kayunga districts: A new and devastating disease. The first updated disease report. NARO/KARI.

Urwin PE, Lilley CJ, McPherson MJ, Atkinson HJ (1997). Resistance to both cyst and root knot nematodes conferred by transgenic Aradopsis expressing a modified plant cystatin. Plant J.12:455-461.

Urwin PE, Troth KM, Zubko El, Atkinson HJ (2001). Effective transgenic resistance to Globodera pallida in potato field trials. Mol. Breed. 8:95110.

Urwin PE, Atkinson HJ, Waller DA, McPherson MJ (1995). Engineered oryzacystatin-I expressed in transgenic hairy roots confers resistance to Globodera pallida. Plant J. 8:121-31 Vain, P., Worland, B., Clarke, M.C., Richard, G., Beavis, M., et al. (1998). Expression if an engineered cysteine protease inhibitor (Oryzacystatin-I1D86) for nematode resistance in transgenic rice plants. Theor. Appl. Genet. 96:266-271.

Urwin PE, Green J, Atkinson HJ (2003) Expression of a plant cystatin confers partial resistance to Globodera, full resistance is achieved by pyramiding a cystatin with natural resistance. Mol. Breed. In press.

Urwin PE, Levesley A, McPherson MJ, Atkinson HJ (2000) Transgenic resistance to the nematode Rotylenchulus reniformis conferred by $A$. thaliana plants expressing protease inhibitors. Mol. Breed. 6:257264.

Urwin PE, McPherson MJ, Atkinson HJ (1998) Enhanced transgenic plant resistance to nematodes by dual protease inhibitor constructs. Planta 204:472-479.

Vain P, Worland B, Clarke MC, Richard G, Beavis M, et al. (1998). Expression if an engineered cysteine protease inhibitor (Oryzacystatin-I1D86) for nematode resistance in transgenic rice plants. Theor. Appl. Genet. 96:266-271.

Wei JZ, Hale K, Cara L, Platzer E, Wong C, Fang SC, Raffi V (2003). Bacillus thuringiensis crystal proteins that target nematodes. Proc. Natl. Acad. Sci. USA 10:2760-2765.

Yun DJ, Bressan RA, Hasegawa PM (1997). Plant antifungal proteins. Plant Breeding Rev.14: 39-88.

Zasloff M (1987) Magainins, a class of antimicrobial peptides from Xenopus skin: isolation, characterization of two active forms and partial cDNA sequence of a precursor. Proc. Natl. Acad. Sci. USA 84:5449-5453.

Zidenga $T$ (2003). The status of biosafety in Africa. http://www.isb.vt.edu/news/2003/news03.jul.html. 